\title{
ROCK MAGNETIC AND PALAEOMAGNETIC ANALYSES ON LITHIC FRAGMENTS FROM THE ARCHAEOLOGICAL SITE OF AKROTIRI, SANTORINI
}

\author{
Tema E. ${ }^{1}$ \\ ${ }^{1}$ Dipartimento di Scienze della Terra, Università degli Studi di Torino, via Valperga Caluso 35, \\ 10123, Torino, Italy, evdokia.tema@unito.it
}

\begin{abstract}
Rock magnetic and palaeomagnetic analyses on lithic clasts collected from the pumice fall deposited inside the archaeological site of Akrotiri have been applied in order to estimate the deposition temperature of the first volcanic products of the Minoan eruption. A total of 50 lithic clasts have been collected from four different locations inside the excavation of Akrotiri. All samples have been stepwise thermally demagnetized and the obtained results have been interpreted through principal component analysis. The equilibrium temperature obtained after the deposition of the pumice fall varies from sample to sample but generally shows temperatures around 240-280 $\mathrm{C}$. These temperatures are in good agreement with those estimated from lithic clasts from the Megalochori Quarry while they are higher compared with those from ceramic fragments from Akrotiri. The new temperature data presented here show that the pumice fall was still relatively hot when deposited inside the archaeological site and even if it interacted with the buildings, often causing the collapse of roofs, it still remained hot with mean temperature around $260^{\circ} \mathrm{C}$.
\end{abstract}

Keywords: Rock magnetism, Pumice fall, Lithic clast, Akrotiri archaeological site, Santorini.

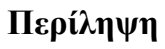

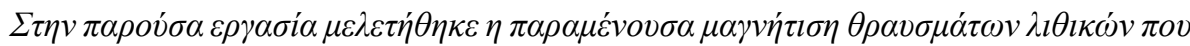

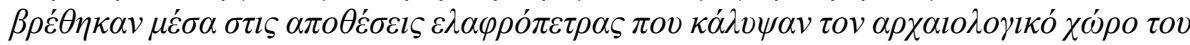

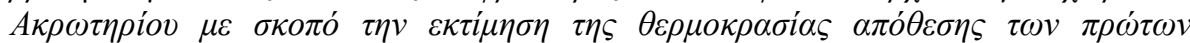

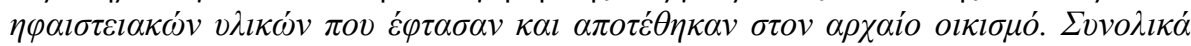

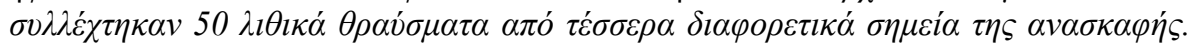

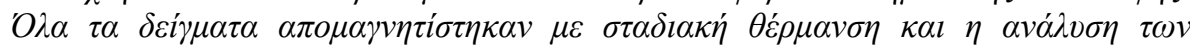

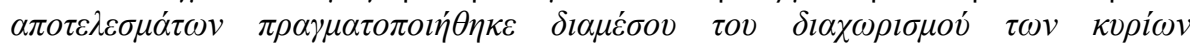

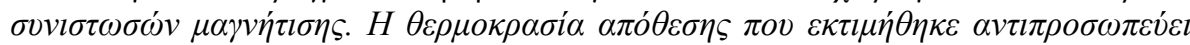

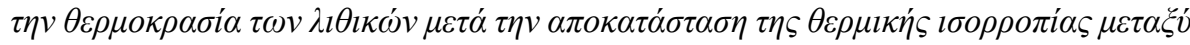

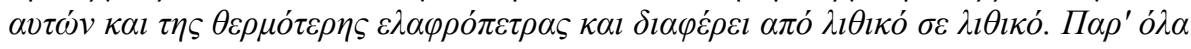

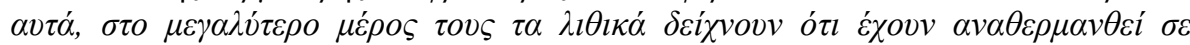

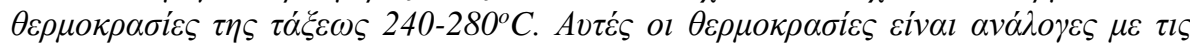

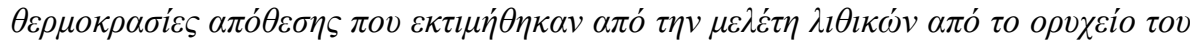

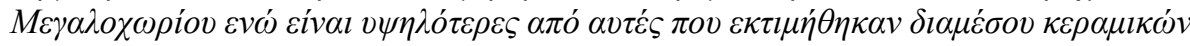

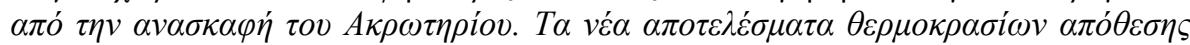

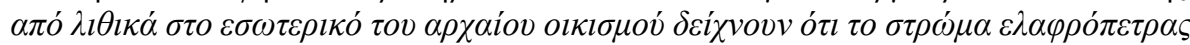

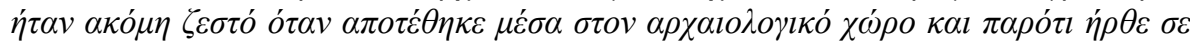




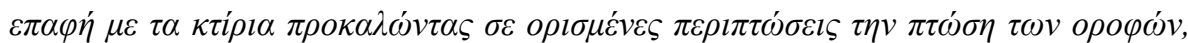

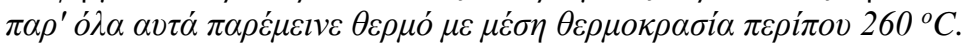

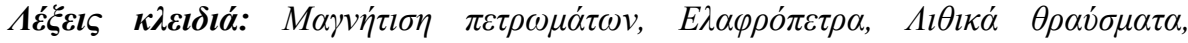

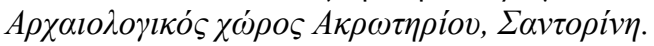

\section{Introduction}

The Akrotiri archaeological site is located at the southern part of Santorini Island and is one of the most important Bronze Age human settlements in the Mediterranean area. The ancient city was destroyed and at the same time preserved under meters of pyroclastic deposits, produced by the violent Minoan eruption of Santorini volcano. Archaeological excavation brought into light a very advanced civilization and a well developed habitation settlement while at the same time gave evidence of important earthquake activity that took place before and during the destructive volcanic event (Doumas, 1974). The stratigraphy of the Minoan eruption inside the archaeological site of Akrotiri shows that most of the streets and squares were covered by a building debris layer produced by the partial destruction of the settlements due to the earthquakes preceding the Minoan eruption. This destruction layer was then covered by a thin layer of ash probably produced during the early opening phase of the eruption (Cioni et al., 2000). The first product of the main eruption deposited at Akrotiri was a Plinian pumice fallout (Figure 1) with minimum thickness of $120 \mathrm{~cm}$ that locally arrive up to 170-200 cm, due to preferential accumulations close to the buildings (Cioni et al., 2000). Over the pumice fall, pyroclastic surge deposits belonging to the second phase of the eruption were deposited in cross-stratified layers, completely burying the whole settlement. The massive, lithicrich pyroclastic flow deposits of the successive phase of the eruption are missing from the Akrotiri archaeological site, probably deviated by, and/or channelled around the settlement into the topographic lows (Cioni et al., 2000).

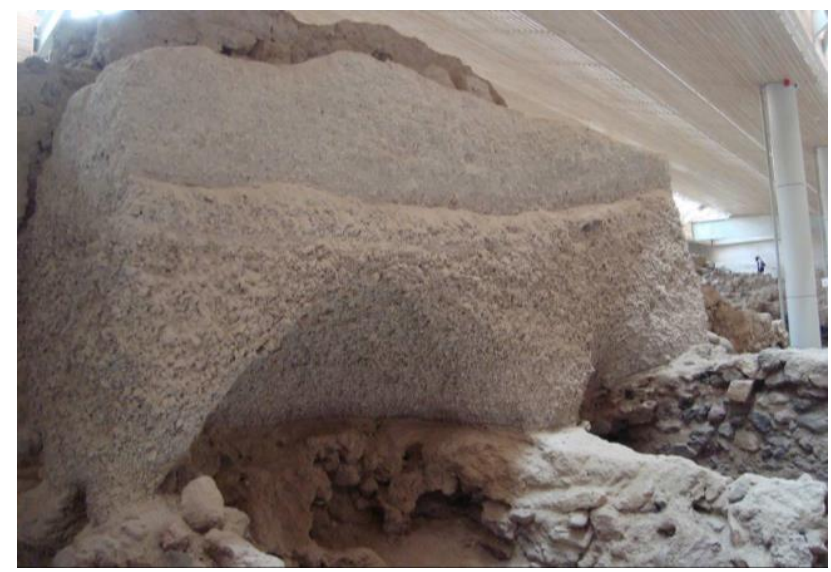

Figure 1 - View of the pumice fall deposited inside the archaeological site of Akrotiri.

Even though the stratigraphy of the Minoan eruption volcanic deposits has been thoroughly studied by several researchers (e.g. Bond and Sparks, 1976; Heiken and McCoy, 1984; Druitt et al., 1989; Sparks and Wilson, 1990; McCoy and Heiken, 2000), available information regarding the temperatures of the pyroclastic products when deposited inside the archaeological site and their effect on the human settlements is still scarce.

Aramaki and Akimoto (1957) were the first to use rock magnetic and palaeomagnetic analysis to obtain information regarding the deposition temperature of pyroclastic rocks. Since then, several studies used lithic clasts embedded in volcanic deposits to better understand their characteristics and estimate their deposition temperature (e.g. Downey and Tarling, 1984; McClelland and Druitt, 1989; McClelland et al., 1996; Bardot, 2000; Cioni et al., 2004; Zanella et al., 2007; Sulpizio et al., 2008; Paterson et al., 2010). In this study, standard palaeomagnetic techniques have been applied for first 
time on lithic clasts from the pumice fallout deposited inside the Akrotiri archaeological site in order to estimate the deposition temperature of the pyroclastic deposits and better understand their characteristics when interacting with human constructions.

\section{Materials and Methods}

\subsection{Samples collection and preparation}

Lithic clasts embedded into the first pumice fall layer were collected from four different locations inside the archaeological site of Akrotiri (Figure 2). During the last decades most of the volcanic deposits that covered the ancient city have been removed and therefore sampling was limited only at the parts of the settlement where the pumice fall and the overlaying pyroclastic surge deposits were preserved as stratigraphic testimonies. All samples collected have dimensions ranging from 1 $\mathrm{cm}$ to $3 \mathrm{~cm}$.

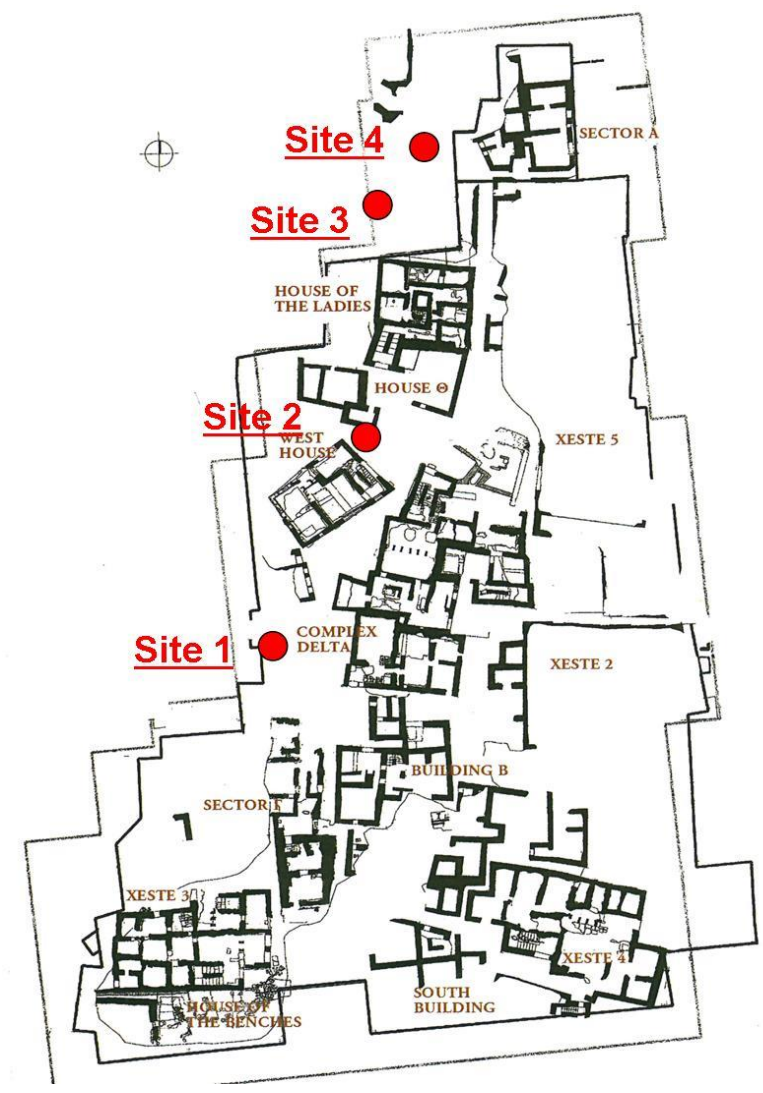

Figure 2 - Map of the Akrotiri excavation with the location of the sampling sites.

When possible, each lithic clast was divided at the laboratory in two small pieces and each of them was fixed into cubic palaeomagnetic boxes of standard dimensions $(2 \times 2 \times 2 \mathrm{~cm})$ using a smooth, white, non magnetic plasticine. This way, often two specimens from the same sample were prepared and studied. Even though samples were not oriented in situ, a white arrow was marked on their surface to facilitate the laboratory measurements. The samples were removed from the plastic boxes for the heating treatment while the use of the plasticine allowed their reposition at exactly the same position for the remanent magnetization measurement. A total of 74 specimens coming from 50 independent lithic clasts have been analysed; 20 from Site 1 (L1FKL), 19 from Site 2 (L1FOG), 12 from Site 3 (ATHL1) and 23 from Site 4 (AMTA). 


\subsection{Experimental procedure}

The use of palaeomagnetic techniques to estimate the emplacement temperature of pyroclastic deposits is based on the assumption that during an explosive eruption, cold lithic clasts coming from the existing volcanic structure, are incorporated and heated into a hot mixture of ash and gases that is eventually deposited in certain distance from the eruption vent. The accidental lithic clasts will have a primary magnetization acquired prior to the eruption. If the pyroclastic deposits were emplaced above ambient temperature, the clasts will be then partially reheated during their incorporation into the deposit and a portion of their initial magnetization will be cancelled. A new secondary magnetization will thus be acquired during their cooling in the presence of the ambient Earth's magnetic field. This procedure produces two components of magnetization that can be isolated with progressive thermal demagnetization (Cioni et al., 2004; Paterson et al., 2010; Tema et al., 2013a; Zanella et al., 2015).

In this study, stepwise thermal demagnetization was carried out using a Schonstedt furnace for heating and cooling and JR5/JR6 spinner magnetometers for measuring the remanent magnetization. Thermal demagnetizations were carried out in steps of $40^{\circ} \mathrm{C}$ between a starting temperature of $60^{\circ} \mathrm{C}$ and a maximum temperature varying between $500^{\circ} \mathrm{C}$ and $580^{\circ} \mathrm{C}$. When twin specimens from individual samples were available, a second demagnetization group was carried out following the same $40^{\circ} \mathrm{C}$ step but starting from $80^{\circ} \mathrm{C}$. After each temperature step, the bulk magnetic susceptibility was measured with a KLY-3 Kappabridge (AGICO). All measurements were performed at the ALP palaeomagnetic laboratory (Peveragno, Italy).

\section{Results}

\subsection{Magnetic susceptibility variation during heating}

The bulk magnetic susceptibility of all specimens was measured at room temperature after each thermal demagnetization step in order to detect possible mineralogical changes during heating (Porreca et al., 2007; Paterson et al., 2010, Tema et al., 2013a, 2015). The obtained values have been normalized to the initial susceptibility measured before any thermal treatment and plotted versus temperature (Figure 3 ). The results show that often important magnetic susceptibility changes occur during heating and in some cases susceptibility variation may arrive up to $50 \%$ in respect to the initial value (Figure 3a). Such changes may reflect possible mineralogical transformations and the formation of a chemical remanent magnetization (CRM) that can affect the blocking temperature spectrum of a sample, obscuring the reliable isolation of the deposition temperature (McClelland and Druitt, 1989; Paterson et al., 2010).

The obtained results confirm that lithic clasts are less thermally stable than the ceramic fragments embedded into pyroclastic deposits (Tema et al., 2013a, b, 2015), probably because of their unknown and often complicated thermal history. Their interpretation and use for the determination of deposition temperatures could therefore be complicated and should be done with caution. In this study, to guarantee the reliability and the quality of the new results, lithic clasts that show important magnetic susceptibility changes have been rejected and the final results are based only on samples that show a stable thermal behavior up to $400^{\circ} \mathrm{C}$ (Figure 3b) and/or are characterized by a clear interpretation of the secondary magnetic component. 


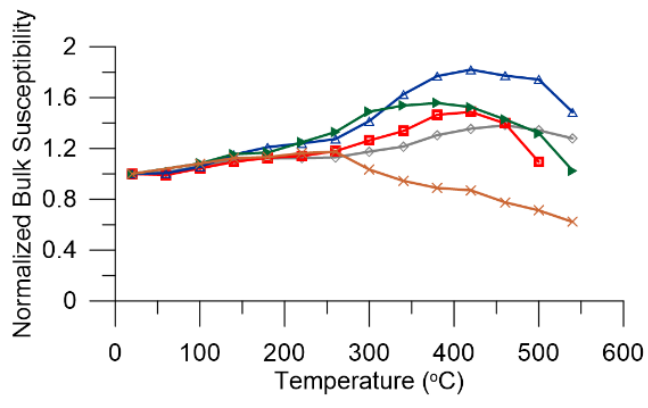

(a)

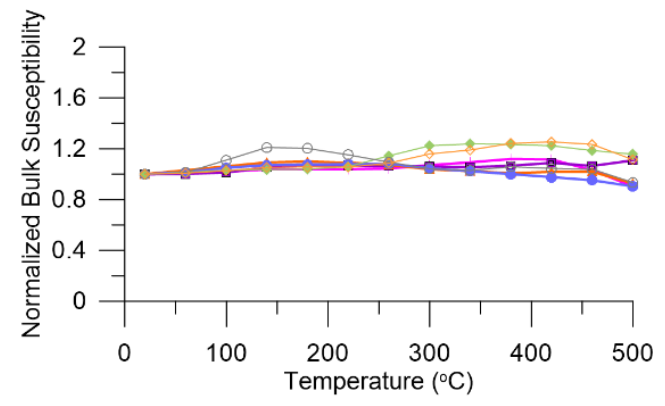

(b)

Figure 3 - Examples of samples with a) important magnetic susceptibility changes and b) stable thermal magnetic behaviour during heating.

\subsection{Magnetic components analysis}

The thermal demagnetization results have been represented using orthogonal vector plots (Zijderveld diagrams, Zijderveld, 1967) (Figure 4). Data have been elaborated using the PaleoMac (Cogné, 2003) software. From the 74 analysed specimens, 45 have been rejected either because of important mineralogical changes during heating or due to not clear interpretation of the Zijdelveld diagrams. The remaining specimens showed a two-magnetic components behavior, belonging to types C and D according to the classification made by Cioni et al. (2004) (Figure 4).
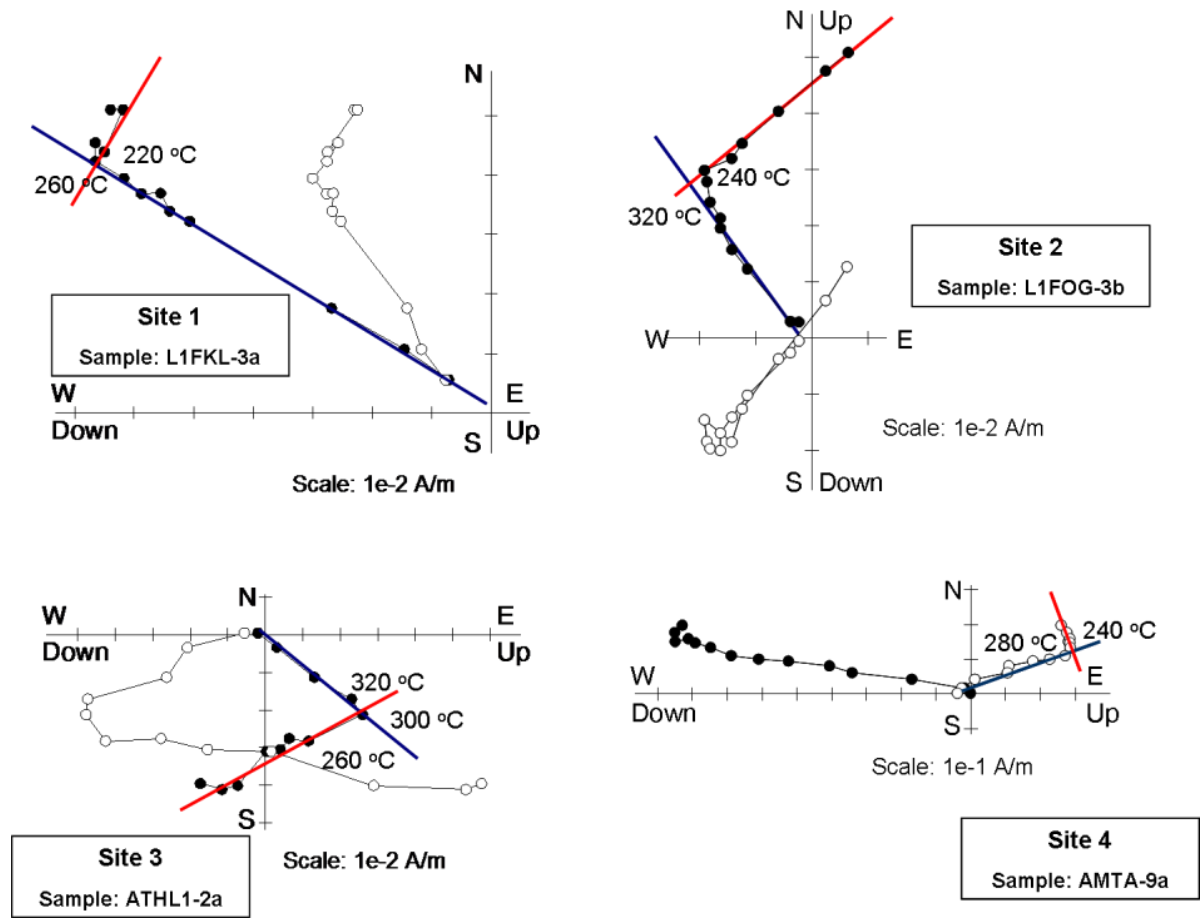

Figure 4 - Thermal demagnetization results represented in Zijderveld diagrams. Solid dot indicates declination; open dot indicates apparent inclination.

The deposition temperature of the pyroclastic deposit in which the lithic clasts were incorporated has been determined from the intersection of the two recognized magnetic components: the primary, high-temperature magnetic component corresponding to the initial magnetization of the clasts (before the Minoan eruption) and the secondary, low-temperature magnetic component acquired 
during the partial reheating of the clast when embedded in the pumice fall (blue and red lines in Figure 4). In the cases of curvature behaviour in the Zijderveld diagrams, the re-heating temperature has been determined taking into account the whole temperature interval between the lowertemperature where the curvature begins up to the first temperature of the high-temperature magnetic component (Tema et al., 2013a). Even if this way the estimated temperature interval results rather wide, it however guarantees that the real deposition temperature would be included into this interval. The re-heating temperature for each site has been finally estimated from the maximum overlap of the re-heating temperatures determined from each studied specimen (Figure 5).

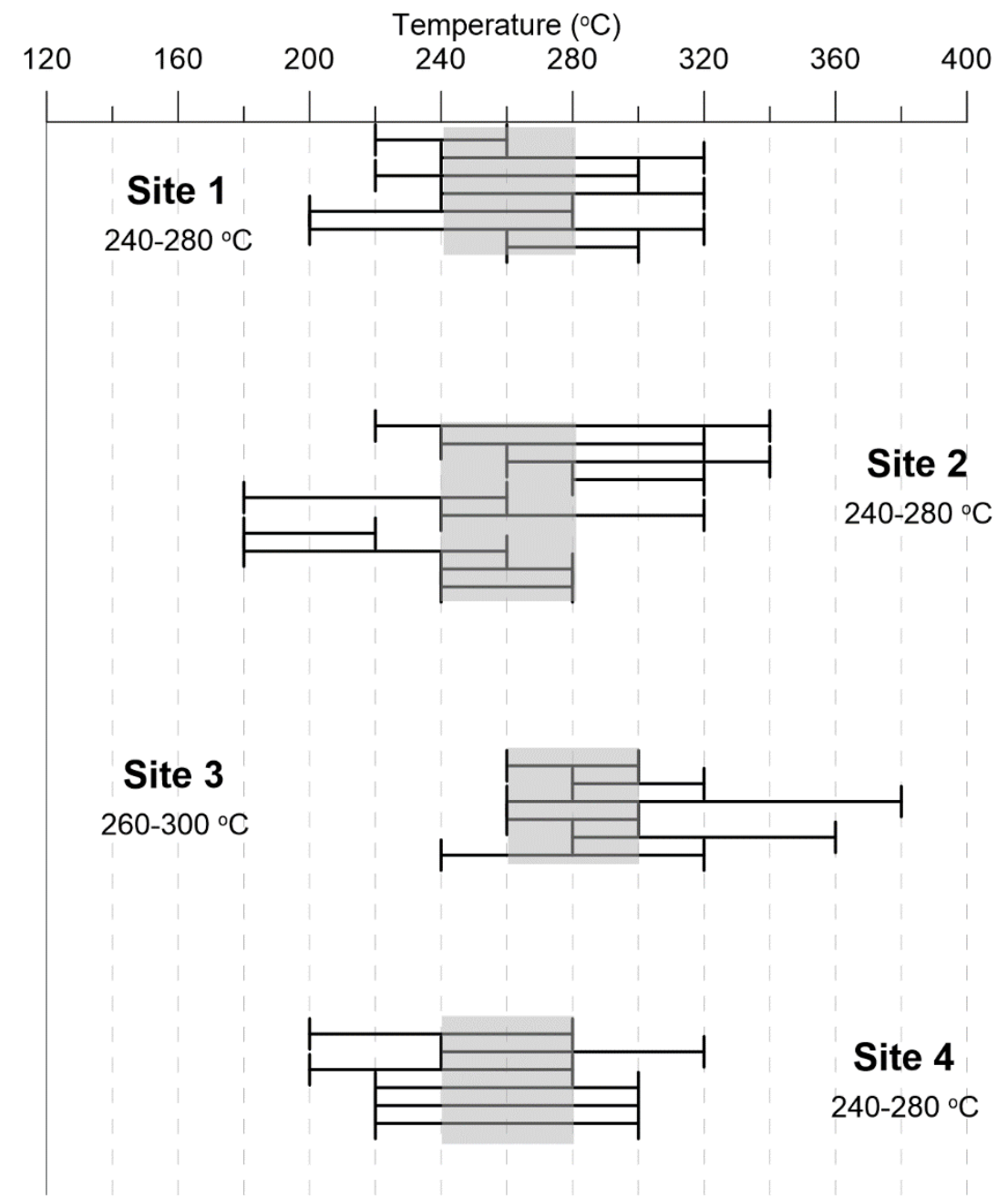

Figure 5 - Deposition temperature of the pyroclastic pumice fall at the four studied sites estimated by the maximum overlap of the re-heating temperatures at specimen level.

\section{Discussion}

The obtained results show that the temperature of the pumice fall, as registered by the lithic clasts embedded into the deposits from the archaeological site of Akrotiri and after the achievement of the thermal equilibrium between the cold lithics and the hotter pumice matrix, is generally ranging from $240^{\circ} \mathrm{C}$ to $300^{\circ} \mathrm{C}$ (Figure 5). Individual specimens, however, may show large temperature ranges occasionally varying from $180^{\circ} \mathrm{C}$ to $380^{\circ} \mathrm{C}$, probably because of the different thermal history of each lithic clast and their unknown transportation path till their incorporation and deposition in the pumice 
fall deposits. Nevertheless, the $97 \%$ of the accepted specimens show a common re-heating temperature interval of $240-280^{\circ} \mathrm{C}$ and no important differences are noticed among the different sampling sites inside the Akrotiri settlement (Figure 5). These results are in good agreement with the results from lithic clasts selected from the Megalochori Quarry (Tema et al., 2013a) that show temperatures in the $180-240^{\circ} \mathrm{C}$ range while are higher than the temperatures obtained based on the study of ceramic fragments from the archaeological site of Akrotiri (Tema et al., 2015), ranging from $130^{\circ} \mathrm{C}$ to $200^{\circ} \mathrm{C}$. Such difference is probably due to the fact that the lithic clasts were embedded inside the hot pumice fall deposit while the ceramic fragments were lying over the building destruction lever and were re-heated only by the superficial contact with the overlying pumice fall deposit. The new temperature data presented here show that the pumice fall was still relatively hot when deposited inside the archaeological site and even if it interacted with the buildings often causing the collapse of roofs, it still remained hot with mean temperature around $260^{\circ} \mathrm{C}$.

\section{Acknowledgments}

Prof. Christos Doumas and Dr. Tania Devetzi are warmly acknowledged for the permission to collect samples from the archaeological site of Akrotiri as well as for their hospitality at the Akrotiri excavation during the sampling campaign. Dr. Giorgos Alexopoulos is thanked for interesting discussions and for providing useful information about the excavation. Prof. Spyros Pavlides and Prof. Despina Kondopoulou are also warmly acknowledged for their continuous support and encouragement. Dr. Elena Zanella is sincerely thanked for introducing me to this interesting world of rock magnetism applied to volcanology. An anonymous reviewer is highly acknowledged for useful comments on the manuscript.

\section{References}

Aramaki, S. and Akimoto, S., 1957. Temperature estimation of pyroclastic deposits by natural remanent magnetism, Am. J. Sci., 255, 619-627.

Bardot, L., 2000. Emplacement temperature determinations of proximal pyroclastic deposits on Santorini, Greece, and their implications, Bull. Volcanol., 61, 450-467.

Bond, A. and Sparks, R.S., 1976. The Minoan eruption of Santorini, Greece, Journal of the Geological Society of London, 132, 1-16.

Cioni, R., Gurioli, L., Sbrana, A. and Vougioukalakis, G., 2000. Precursory phenomena and destructive events related to the Late Bronze Age Minoan (Thera, Greece) and AD 79 (Vesuvius, Italy) Plinian eruptions; inferences from the stratigraphy in the archaeological areas. In: The Archaeology of Geological Catastrophes, McGuire, W.G., Griffiths, D.R., Hancock, P.L. and Stewart, I.S., eds., Geological Society Special Publication, London, 171, 123-141.

Cioni, R., Gurioli, L., Lanza, R. and Zanella, E., 2004. Temperatures of A.D. 79 pyroclastic density currents deposits (Vesuvius, Italy), J. Geophys. Res., 109, B02207, doi: 10.1029/2002JB002251.

Cogné, J.R., 2003. PaleoMac: a Macintosh application for treating palaeomagnetic data and making plate reconstructions, Geochem. Geophys. Geosyst., 4(1), 1007, doi: 10.1029/2001GC000227.

Doumas, Ch., 1974. The Minoan eruption of the Santorini volcano, Antiquity, XLVIII, 110-115.

Downey, W.S. and Tarling, D.H., 1984. Archaeomagnetic Dating of Santorini Volcanic Eruptions and Fired Destruction Levels of Late Minoan Civilization, Nature, 309(5968), 519-523.

Druitt, T.H., Mellors, R.A., Pyle, D.M. and Sparks, R.S.J., 1989. Explosive volcanism on Santorini, Greece. Geol. Mag., 126, 95-126.

Heiken, G. and McCoy, F., 1984. Caldera development during the Minoan eruption, Thera, Cyclades, Greece, J. Geophys. Res., 89, B 10, 8441-8462. 
McClelland, E. and Druitt, D.H., 1989. Palaeomagnetic estimates of emplacement temperatures of pyroclastic deposits on Santorini, Greece, Bull. Volcanol., 51, 16-27, doi: 10.1007/BF01086758.

McClelland, E., Kondopoulou, D., Westphal, M. and Sophos, Ph., 1996. Palaeomagnetic estimation of emplacement temperatures of plinian airfalls on Santorini, Greece. In: Casale, R., Fytikas, M., Sigvaldasson, G. and Vougioukalakis, G., eds., The European laboratory volcanoes, Proceedings of the 2nd workshop, 2-4 May 1996, Santorini, Greece.

McCoy, F. and Heiken, G., 2000. The Late Bronze Age explosive eruption of Thera (Santorini), Greece: Regional and local effect, Geological Society of America, Special paper, 345, 43-70.

Paterson, G.A., Roberts, A.P., Mac Niocaill, C., Muxworthy, A.R., Gurioli, L., Viramonte, J.G. and Navarro, C., 2010. Paleomagnetic determination of emplacement temperatures of pyroclastic deposits: an underutilised tool, Bull Volcanol., 72, 309-330, doi: 10.1007/s00445-009-0324-4.

Porreca, M., Mattei, M., Mac Niocaill, C., Giordano, G., McClelland, E. and Funiciello, R., 2008. Paleomagnetic evidence for low-temperature emplacement of the phreatomagmatic Peperino Albano ignimbrite (Colli Albani volcano, Central Italy), Bull. Volcanol., 70, 877-893, doi: 10.1007/s00445-007-0176-8.

Sparks, R.S.J. and Wilson, C.J.N., 1990. The Minoan deposits: a review of their characteristics and interpretation. In: Hardy, D., Keller, J., Galanopoulos, V.P., Flemming, N.C. and Druitt, T.H., eds., Thera and theAegean World III, vol. 2. The Thera Foundation, London, 89-99.

Sulpizio, R., Zanella, E. and Macías, J.L., 2008. Deposition temperature of some PDC deposits from the 1982 eruption of El Chichón volcano (Chiapas, Mexico) inferred from rock magnetic data, J. Volcanol. Geotherm. Res., 175, 494-500, doi: 10.1016/j.jvolgeores.2008.02.024.

Tema, E., Kondopoulou, D. and Pavlides, S., 2013a. Palaeotemperature estimation of the pyroclastic deposit covering the pre-Minoan palaeosol at Megalochori Quarry, Santorini (Greece): Evidence from magnetic measurements, Stud. Geophys. Geod., 57, 627-646, doi: 10.1007/s11200-013-0601-8.

Tema, E., Pavlides, S. and Kondopoulou, D., 2013b. Late Bronze age pottery as indicator of the deposition temperatures of the Minoan pyroclastic products, Santorini, Greece, Bulletin of the Geological Society of Greece, XLVII, Proceedings of the 13th International Congress, Chania, Sept. 2013.

Tema, E., Zanella, E., Pavón-Carrasco, F.J., Kondopoulou, D. and Pavlides, S., 2015. Palaeomagnetic analysis on pottery as indicator of the pyroclastic flow deposits temperature: new data and statistical interpretation from the Minoan eruption of Santorini, Greece, Geophys. J. Int., 203, 33-47, doi: 10.1093/gii/ggv267.

Zanella, E., Gurioli, L., Pareschi, M.T. and Lanza, R., 2007. Influences of urban fabric on pyroclastic density currents at Pompeii (Italy): 2. Temperature of the deposits and hazard implications, J. Geophys. Res., 112, B05214, doi: 10.1029/2006JB004775.

Zanella, E., Sulpizio, R., Gurioli, L. and Lanza, R., 2015. Temperatures of the pyroclastic density currents deposits emplaced in the last $22 \mathrm{kyr}$ at Somma-Vesuvius (Italy). Geological Society, London, Special Publication: "The Use of Palaeomagnetism and Rock Magnetism to Understand Volcanic Processes", 396, doi:10.1144/SP396.5.

Zijderveld, J.D.A., 1967. A.C. demagnetization of rocks: Analysis of results. In: Methods in Palaeomagnetism, Collinson, D.W., Creer, K.M. and Runcorn, S.K., eds., Elsevier, Amsterdam. 